Virtue's Splendor 
Moral Philosophy and Moral Theology Series

Romanus Cessario, O.P., and Joseph W. Koterski, S.J., series editors

1. Martin Rhonheimer, Natural Law and Practical Reason. Translated by Gerald Marlsbary.

2. Anton Losinger, The Anthropological Turn: The Human Orientation of the Theology of Karl Rahner. Translation with a foreword by Daniel O. Dahlstrom. 


\title{
Virtue's Splendor
}

\section{WISDOM, PRUDENCE, AND THE HUMAN GOOD}

\author{
THOMAs S. HibBS
}

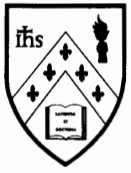

Fordham University Press

New York

2001 


\section{Copyright (C) 2001 by Fordham University Press}

All rights reserved. No part of this publication may be reproduced, stored in a retrieval system, or transmitted in any form or by any means - electronic, mechanical, photocopy, recording, or any other-except for brief quotations in printed reviews, without the prior permission of the publisher.

Moral Philosophy and Moral Theology Series, No. 3

ISSN 1527-523X

\section{Library of Congress Cataloging-in-Publication Data}

Hibbs, Thomas S.

Virtue's splendor : wisdom, prudence, and the human good / Thomas S.

Hibbs.-1st ed.

p. $\quad$ cm.-(Moral philosophy and moral theology ; no. 3)

Includes bibliographical references and index.

ISBN 0-8232-2043-5 (alk. paper)—ISBN 0-8232-2044-3 (pbk. : alk. paper)

1. Christian ethics. I. Title. II. Series.

BJ1249.H53 2001

$170-\mathrm{dc} 21$

2001042494

$\begin{array}{llllllllll}01 & 02 & 03 & 04 & 05 & 5 & 4 & 3 & 2 & 1\end{array}$

First Edition 
Ut Tullius dicit, "ex justitia praecipue viri boni nominantur," unde, sicut dicit, "in ea virtutis splendor est maximus."

Thomas Aquinas, Summa Theologiae, II-II, 58, 3 